southwest corner of Second Cranberry Lake on June 25, 1962. This is less than 25 miles southwest of Flin Flon. As noted above, large numbers of Common Loons have been seen in summer within 50 miles of Flin Flon in 1943, 1946, 1963, 1970, 1971 and 1972. Bushree's record provides further evidence that the lakes in this region attract large numbers of loons.

In correspondence with Bushree dated August 27, 1962, C. H. D. Clarke, then Chief of the Ontario Fish and Wildlife Branch, stated: "During the summer months, loons may be seen along the Hudson Bay coast in groups of ten and fifteen, but none of us has noticed any flocks as large as two hundred and fifty to three hundred birds. Since the mature male and female birds both engage in nesting and brooding of young, it is probable that the birds you saw were non-breeding birds. I do not believe that we are entirely sure at what age the loon becomes active in breeding, but it is possible that they do not breed until their third or fourth year of life and that the flocks of loons which are seen are non-breeding birds of one and two years. During the early spring there are large flocks of loons on the southern portion of Lake Huron but these are birds seen in migration. In addition, the same flocks occur occasionally during the fall."

\section{ALBERTA ORNITHOLOGICAL RECORDS COMMITTEE}

\section{The Federation of Alberta} Naturalists are pleased to announce the establishment of the Alberta Ornithological Records Committee under the chairmanship of Dr. W. Ray Salt. The Committee is composed of seven members, five from Alberta and one each from British Columbia an Saskatchewan (Dr. C. S. Houston The Alberta members will constitu the main working group of the Cor mittee, with the out-of-province men bers being called upon to provide opinion on submitted records wh required.

The Federation believes that $t\}$ Committee will fill a need and $w$ provide a degree of authenticity records of sighting and breeding birds in Alberta. We wish to encoura Albertan naturalists and visitors to of Province to submit details of obse vations of species of birds seen various areas of Alberta and especial rare and unusual species of birds.

There are two main functions of $t$ Alberta Ornithological Records Cor mittee (AORC):

1. The AORC will serve as repository for records of birds fro any and all parts of Alberta. The Cor mittee welcomes reports on Alber birds in any form but a report for called by the Committee an Area Li will be printed and will be availab for distribution early in 1974. records should be sent to: $T$ Secretary, Alberta Ornithologic Records Committee, Provinci Museum and Archives of Alber 12845-102 Avenue, Edmonto Alberta, T5N $0 \mathrm{M} 6$.

NOTE: It should be emphasized th this form, the Area List, is not inte ded to replace, nor to be used as a su stititute for, the individual reco cards currently being used by sever Societies of Naturalists in Alberta.

2. The AORC, when requested do so, will examine the documentati of records of rare and unusual spec of birds in Alberta. When serving th as an adjudicating body, the Comm tee will place each record in one of $t$ following categories: I. Substantiat Record, II. Documented Observatic III. Documented Nesting Record, I Unsubstantiated Observation, and w advise the observer of its decision.

A list of species and the zones of $t$ Province in which a record would considered unusual will shortly published by the AORC. 